\title{
MODERASI ISLAM (WASATHIYAH ISLAM) PERSPEKTIF AL-QUR'AN, AS-SUNNAH SERTA PANDANGAN PARA ULAMA DAN FUQAHA
}

\author{
Khairan Muhammad Arif \\ Fakultas Agama Islam, Universitas Islam As-Syafiíyah, Indonesia \\ khairanmarif.fai@uia.ac.id
}

\begin{abstract}
Abstrak
Konsep Wasathiyah Islam atau moderasi Islam saat ini telah menjadi arah atau aliran pemikiran Islam yang telah menjadi diskursus penting dalam dunia Islam dewasa ini, melihat kondisi umat Islam yang selalu menjadi tertuduh dalam setiap peristiwa kekerasan yang dilakukan oleh personal muslim yang tidak memahami karakter dan ini ajaran Islam. Oleh karenanya penilitian literatif ini bertujuan memberikan pemahaman dan konsep orisinil tentang aliran pemikiran moderasi islam, agar setiap muslim modern dapat memahami dan mengimplementasikannya dengan benar dan komprehensif dalam kehidupannya sehari-hari. Penelitian ini menggunakan metode kepustakaan dan kajian literasi Islam klasik maupun modern dari Al-Qur'an, As-Sunnah dan kitab-kitab klasik dan modern dari para Ulama dan Fuqaha yang kompeten dibidangnya. Literatur tersebut dikaji dan dianalisa oleh peneliti dengan teliti untuk menghasilkan kesimpulan yang tepat dan teruji. Hasil penelitian ini adalah;

diketahuinya secara pasti makna dan konsep moderasi Islam menurut Al-Qur'an, As-Sunnah dan para Ulama serta menjawab keraguan sebagian muslim terhadap konsep moderasi Islam
\end{abstract}

The concept of Wasathiyah Islam or the current Islamic moderation has become the direction or the flow of Islamic thought that has become an important discourse in the Islamic world today, see the condition of Muslims who have always become accused in every event Violence committed by personal Muslims who do not understand the character and this teachings of Islam. Therefore, this literative study aims to provide an original understanding and concept of the flow of Islamic moderation thinking, so that every modern Muslim can understand and implement it properly and comprehensively in its life.This research uses a method of literature and study of classical and modern Islamic literacy from the Qur'an, As-Sunnah and the classical and modern books of scholars and Fuqaha who are competent in their field. The literature is examined and analysed by researchers carefully to produce precise and proven conclusions. The results of this research are; To be sure the meaning and concept of moderation of Islam according to the Qur'an, As-Sunnah and scholars and answer the doubt of some Muslims on the concept of moderation Islam

Keywords: moderation, Qur'an, As-Sunnah, scholars 


\section{Pendahuluan}

Wasathiyah adalah ajaran Islam yang mengarahkan umatnya agar adil, seimbang, bermaslahat dan proporsional, atau sering disebut dengan kata "moderat" dalam semua dimensi kehidupan. Wasathiyah atau moderasi saat ini telah menjadi diskursus dan wacana keIslaman yang diyakini mampu membawa umat Islam lebih unggul dan lebih adil serta lebih relevan dalam berinteraksi dengan peradaban modern di era globalisasi dan revolusi industri, informasi dan komunikasi. Wasathiyah Islam bukanlah ajaran baru atau ijtihad baru yang muncul di abad 20 masehi atau 14 hijriyah. Tapi wasathiyah Islam atau moderasi Islam telah ada seiring dengan turunnya wahyu dan munculnya Islam di muka bumi pada 14 abad yang lalu. Hal ini dapat dilihat dan dirasakan oleh umat Islam yang mampu memahami dan menjiwai Islam sesuai dengan orisinalitas nashnya dan sesuai dengan konsep dan pola hidup Nabi Muhammad saw, sahabat dan para salaf shaleh.

Arah pemikiran Islam "wasathiyah" ini menjadi sesuatu yang baru dan fenomenal dalam narasi dan pemikiran Islam global, karena disegarkan kembali dan diperkenalkan kembali oleh seorang mujtahid abad 21, yaitu yang mulia Al-Imam Profesor Doktor Yusuf Al-Qaradhawi, seorang ulama besar dari Qatar kelahiran Mesir, alumni Universitas terkemuka di dunia, Al-Azhar Mesir. Karya-karyanya baik dalam bentuk buku, makalah ilmiah, ceramah ataupun sepak terjangnya dalam gerakan dakwah Islamiyah di seluruh dunia, seluruhnya berlandaskan konsep Islam moderat atau wasathiyatul Islam, sehingga para Ulama dunia dan masyarakat Islam internasional menerimanya dengan baik dan menjadikannya sebagai konsep pemikiran baru sebagai prinsip implementasi Islam yang rahmatam lilalamin.

Konsep pemikiran moderasi Islam atau wasathiyatul Islam menjadi menarik dan menjadi impian semua entitas, gerakan dakwah Islam bahkan Negara-negara Islam, setelah dunia Islam dirisaukan dengan munculnya dua arus pemikiran dan gerakan yang mengatasnamakan Islam. Pemikiran dan gerakan pertama, mengusung model pemikiran dan gerakan yang kaku dan keras, atau sering disebut dengan Al-Khawarij al-judud (New Khawarij). Kelompok ini melihat bahwa Islam adalah agama nash dan konstan, tidak menerima perubahan dan hal-hal baru dalam ajaran-ajarannya khususnya dalam akidah, ibadah, hukum dan muamalat, sehingga perlu membersihkan anasir-anasir syirik dan bid'ah dari akidah, ibadah, hukum dan muamalat umat. Paham dan pemikiran ini telah menimbulkan kesan negative terhadap Islam, bahkan melahirkan stigma buruk terhadap Islam sebagai agama yang keras, tertutup, radikal intoleran dan tidak humanis.

Sementara arus pemikiran dan gerakan kedua yang juga mengatasnamakan Islam, adalah pemikiran dan gerakan liberasi Islam, atau sering disebut dengan Muktazilah aljudud (new muktazilah), yang mengusung narasi dan pemikiran rasionalis dan kebebasan penuh terhadap Islam. Gerakan ini melihat bahwa Islam adalah agama rasional dan cair terhadap semua budaya dan perkembangan zaman. Sehingga Islam harus berubah dan mengikuti perkembangan zaman dalam syari'ah, kaifiyat ibadah, 
hukum, muamalat bahkan sebagian akidahnya ${ }^{1}$. Bila arus pemikiran pertama kaku, keras dan tidak mudah menerima hal-hal baru dalam agama, maka arus pemikiran atau arah pemikiran kedua berpendapat sebaliknya, mereka menerima semua perubahan, membolehkan semua hal-hal baru kedalam Islam termasuk pemikiran, budaya dan kehidupan barat. Alian ini berani memastikan bahwa ada nash-nash Al-Qur'an dan AsSunnah yang tidak lagi releven dalam kehidupan manusia modern.

Para Ulama Islam modern, menyadari kondisi benturan dua arus pemikiran yang saling bertentangan ini, antara arus pemikiran ekstrim kanan (tafrith) dan ekstrim kiri (ifrath), sangat berbahaya bagi peradaban Islam dan kehidupan umatnya dalam persaingan peradaban dunia. Oleh karena itu ulama-ulama Islam wasathiy (moderat), seperti Rasyid Ridha murid Muhammad Abduh, Hasan Al-Banna, Abu Zahrah, Mahmud Syalthout, Syekh Muhammad Al-Madani, Syekh At-Thahir Ibnu Asyur, Muhammad Abdullah Darraz, Muhammad Al-Ghazali, Yusuf Al-Qardhawi, Wahbah Ad-dzuhaili, Ramadhan Al-Buthiy dan lainnya. Para ulama ini mulai berusaha mengarahkan umat Islam untuk memahami dan mengimplementasikan ajaran Islam yang wasathiy.

\section{Wasathiyah Islam (Moderasi Islam) dalam Al-Qur'an}

Al-Qur'an telah disepakati secara consensus (Ijma') oleh para Ulama Islam setiap generasi dari masa Rasulullah SAW sampai kiamat, bahwa dia adalah referensi utama dan tertinggi dalam Islam, baik secara akidah dan syar'at maupun secara ilmiah. Al-Qur'an telah menjelaskan dengan mendasar, akuratif dan relevan tentang hakikat arah pemikiran washathiyah dalam kehidupan umat Islam pada banyak ayat dalam AlQur'an. Dari isyarat Al-Qur'an ini lahirlah pandangan-pandangan dan konsep serta manhaj moderasi Islam dalam setiap aspek kehidupan umat. lalu bagaimana pengertian dan hakikat washathiyah menurut Al-Qur'an?.

Muhammad Ali As-Shalabiy (2007M) telah menulis dengan baik dan mumpuni tentang manhaj Al-Washathiyah dalam Al-Qur'an lewat Thesis Magisternya di Universitas Ummu Darman Sudan yang diterbitkan oleh Mu'assasah Iqro, Mesir tahun 2007, dengan Judul “Al-Washathiyah fil Qur'an Al-Karim. Menurut As-Shalabi bahwa akar kata Washathiyah terdapat dalam 4 (empat) kata dalam Al-Qur'an dengan arti yang hampir mirip².

\subsection{Wasathiyah bermakna sikap adil dan pilihan}

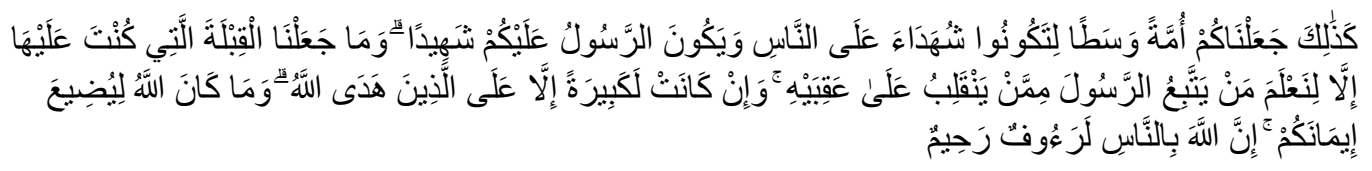

\footnotetext{
${ }^{1}$ Lihat pikiran-pikiran Fuad Zakaria, Husain Ahmad Amin, Said Al-Asymawi dan Faraj Faudah tentang liberasi Islam dalam Muhammad Al-Khair Abdul Qadir, Ittijahaat Haditsah fi Al-Fikr Al-Almani, (Khurtum: Ad-Daar As-Sudaniyah Lil Kutub, 1999), hal 11-23.

2 Ali Muhammad As-Shalabiy, Al-Wasathiyah fil Qur'an Al-Karim, hal 16-25
} 
"Dan demikian (pula) Kami telah menjadikan kamu (umat Islam), umat yang adil dan pilihan agar kamu menjadi saksi atas (perbuatan) manusia dan agar Rasul (Muhammad) menjadi saksi atas (perbuatan) kamu". (QS. Al-Baqarah: 143)

Dari Abu Said Al-Khudri ra, Nabi saw menjelaskan makna ummatan wasathan dalam ayat ini adalah "keadilan" (HR. Tirmidzi, Shahih). At-thabari juga menjelaskan bahwa makna "wasathan" bisa berarti "posisi paling baik dan paling tinggi" 3 . AtThabari mengutip Ibnu Abbas ra, Mujahid dan Atha' saat menafsirkan ayat 143 berkata: "Ummatan Washathan adalah "keadilan" sehingga makna ayat ini adalah "Allah menjadikan umat Islam sebagai umat yang paling adil"4. Al-Qurthubi berkata: wasathan adalah keadilan, karena sesuatu yang paling baik adalah yang paling adil"5. Ibnu Katsir berkata: wasathan dalam ayat ini maksudnya paling baik dan paling berkualitas"6. Para ahli tafsir lain seperti Abdurrahman As-Sa'diy dan Rasyid Ridha menafsirkan bahwa makna washathan dalam ayat ini adalah keadilan dan kebaikan"7.

Dari beberapa hadits Nabi saw dan penjelaskan para mufassir dari kalangan Sahabat dan tabi' in serta para mufassir generasi setelahnya sampai mufassir modern di atas, dapat disimpulkan makna wasathan pada surat Al-Baqarah 143 ini adalah; "Keadilan dan kebaikan, atau umatan wasathan adalah umat yang paling adil dan paling baik".

\subsection{Wasathiyah bermakna paling baik dan pertengahan}

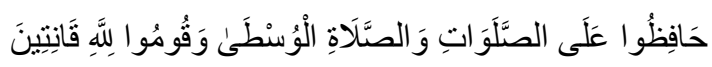

"Peliharalah semua shalat(mu), dan (peliharalah) shalat wusthaa. Berdirilah untuk Allah (dalam shalatmu) dengan khusyu"'. (QS. Al-Baqarah: 238)

Para Ahli tafsir seperti At-Thabari berkata bahwa makasudnya adalah Shalat Ashar, karena terletak di tengah-tengah shalat lain antara subuh dan zuhur serta maghrib dan isya". AL-Qurthubi berkata: "Al-Wustha bentuk feminism dari kata wasath yang berarti terbaik dan paling adil"'. Menurut Ibnul Jauziy, maksud ayat ini ada 3 makna: pertama: Terkait dengan shalat yang terletak pada pertengahan, kedua: paling tengah ukurannya dan ketiga: karena paling afdhal kedudukannya"10. Jadi tidak ada kata

3 Ibnu Jarir At-Thabari, Tafsir At-Thabari, vol 2 (Kairo: Maktabah At-Taufiqiyah, 2004), hal 7, lihat

4 Ibid, hal 8

5 Muhammad bin Ahmad Al-Anshari Al-Quthubi, Al-Jami' Li Ahkam Al-Quran (Tafsir AlQurthubi), vol 1, (Kairo: Maktabah Al-Iman, tt), hal 477

6 Ibnu Katsir, Tafsir Al-Quran Al-adzim, vol 1, (Beirut: Daar Al-Fikri, 1994), hal 237

7 Ali Muhammad As-Shalabiy, Al-Wasathiyah fil Qur'an Al-Karim, hal 17

8 Ibnu Jarir At-Thabari, Tafsir At-Thabari, vol 2, hal 567

9 Al-Quthubi, Al-Jami' Li Ahkam Al-Quran (Tafsir Al-Qurthubi), vol 1, hal 296

10 Ali Muhammad As-Shalabiy, Al-Wasathiyah fil Qur'an Al-Karim, hal 20 
makna lain dari kata wustha dalam ayat ini selain "paling tengah, paling adil dan paling baik.

\subsection{Wasathiyah bermakna paling adil, ideal paling baik dan berilmu}

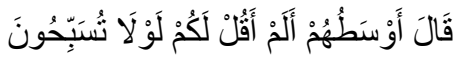

"Berkatalah seorang yang paling baik pikirannya di antara mereka: "Bukankah aku telah mengatakan kepadamu, hendaklah kamu bertasbih (kepada Tuhanmu)?" (QS. AlQalam: 28)

Ibnu Abbas ra dan At-Thabari berkata: Bahwa yang diamaksud dengan kata aushatuhum adalah "Orang yang paling adil dari mereka"11. Al-Qurthubi menafsirkan ayat 28 surat Al-Qalam ini adalah "orang yang paling Ideal, paling adil dan paling berakal dan paling berilmu"12. Dalam ayat ini juga dapat dismpulkan bahwa makna akata ausathuhum adalah "paling adil, paling baik atau ideal dan paling berilmu".

\subsection{Wasathiyah bermakna di tengah-tengah atau pertengahan}

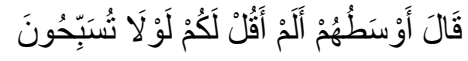

"Dan kuda-kuda perang menyerbu ke tengah-tengah kumpulan musuh" (QS. AlAdiyat: 5)

At-Thabari, Al-Qurthubi dan Al-Qasimi berkata: Maksudnya adalah berada ditengahtengah musuh"13 Demikianlah Hakikat Washathiyah dalam Al-Qur'an sesuai dengan penafsiran yang dipercaya dan otoritatif berdasarkan riwayat yang shahih.

Dari empat ayat Al-Qur'an yang berbeda-beda tentang kata wasathiyah di atas, dapat disimpulkan secara pasti bahwa wasathiyah dalam kalimat dan istilah Al-Qur'an adalah keadaan paling adil, paling baik, paling pertengahan dan paling berilmu. Sehingga umat Islam adalah umat yang paling adil, paling baik, paling unggul, paling tinggi dan paling moderat dari umat yang lainnya.

\subsection{Wasathiyah dalam As-Sunnah}

Untuk menguatkan hujjah bagi mereka yang masih menolak manhaj wasathiyah, penulis mengutip beberapa hadits Nabi saw yang terkait dengan makna wasathiyah Islam. Dalam As-Sunnah, Washathiyah ternyata telah diucapkan dan dilafadzkan oleh Nabi Muhammad saw dalam beberapa haditsnya, yang dapat dimaknai secara bahasa. Nabi terkadang menyebut wasath bermakna keadilan, ketinggian, keberkahan, terbaik dan seimbang seperti dalam hadits-hadits berikut:

\section{Wasathan (moderat) bermakna keadilan}

11 Ibnu Jarir At-Thabari, Tafsir At-Thabari, vol 16, hal

12 Al-Quthubi, Al-Jami' Li Ahkam Al-Quran (Tafsir Al-Qurthubi), vol 10, hal 126

13 Ali Muhammad As-Shalabiy, Al-Wasathiyah fil Qur'an Al-Karim, hal 25 


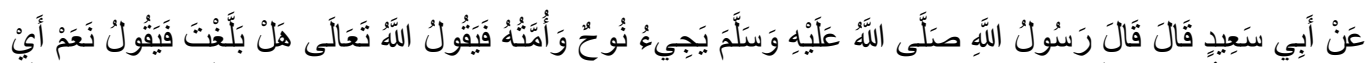

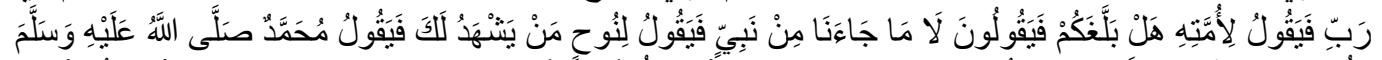

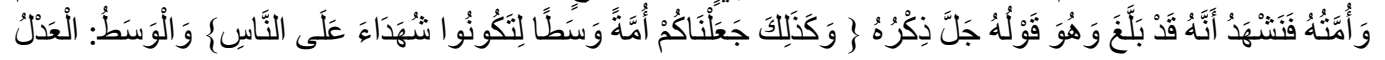

Dari Abu Sa'id berkata; Rasulullah shallallahu 'alaihi wasallam bersabda: "(Pada hari qiyamat) Nabi Nuh 'alaihissalam dan ummatnya datang lalu Allah Ta'ala berfirman: "Apakah kamu telah menyampaikan (ajaran)?. Nuh 'Alaihissalam menjawab: "Sudah, wahai Rabbku". Kemudian Allah bertanya kepada ummatnya: "Apakah benar dia telah menyampaikan kepada kalian?". Mereka menjawab; "Tidak. Tidak ada seorang Nabi pun yang datang kepada kami". Lalu Allah berfirman kepada Nuh 'alaihissalam: "Siapa yang menjadi saksi atasmu?". Nabi Nuh Alaihissalam berkata; "Muhammad shallallahu 'alaihi wasallam dan ummatnya". Maka kami pun bersaksi bahwa Nabi Nuh 'alaihissalam telah menyampaikan risalah yang diembannya kepada ummatnya. Begitulah seperti yang difirmankan Allah Yang Maha Tinggi (QS al-Baqarah ayat 143 yang artinya), ("Dan demikianlah kami telah menjadikan kalian sebagai ummat pertengahan untuk menjadi saksi atas manusia.."). al-washath artinya al-'adl (adil). (HR. Bukhari, Hadits No. 3091 dan Ahmad, Hadits No 10646).

Dalam hadits di atas, sangat jelas Nabi saw memaknai dan menafsirkan kata "wasathan" adalah "keadilan". Yang dimaksud keadilan di sini adalah, bahwa umat Islam adalah umat yang menempatkan sesuatu sesuai pada tempatnya, menyikapi sesuatu sesuai dengan porsinya dan kedaaanya. Moderat adal jujur dan komitmen tidak mendua serta inkonsisten dalam sikap, sehingga Allah melengkapi surat Al-Baqarah: 143 di atas, setelah menyebut wasathan dengan "agar kalian menjadi saksi-saksi bagi manusia". Dalm Islam seorang saksi haruslah yang adail dan jujur. Nampaknya adil, jujur dan konsisten sangat tepat untuk makna ayat ini, sesuai dengan tafsir dari Nabi saw terhadap ayat ini, yaitu keadilan.

\section{Wasathiyah bermakna posisi tengah penuh keberkahan}

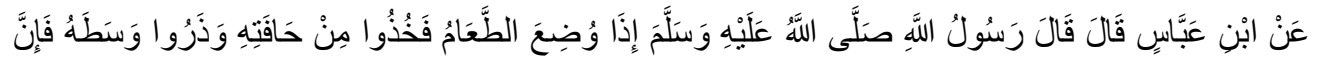

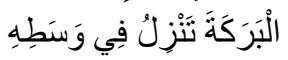

Dari Ibnu Abbas Nabi saw bersabda: “Apabila makanan telah dihidangkan, maka ambillah dari pinggirnya dan tinggalkan tegahnya, sesungguhnya berkah itu turun dibagian tengah" (HR. Ibnu Majah. Hadits No. 3268).

Hadits di atas menjelaskan tentang adab makan, bahwa mengambil makanan hendaknya dimulai dari pinggirnya lalu bagian lainnya. Mengapa demikian? Karena Nabi saw sedang mengajarkan umatnya bagaimana makanan menjadi berkah dan mencukupi untuk orang banyak walaupun makananya sedikit, dengan cara terlebih dahulu mengambil bagian pinggirnya dan membiarkan tengahnya, karena keberkahan makanan diturunkan oleh Allah melalui bagian tengah makanan. Dalam hadits lain Nabi saw bersabda: "Makanan untuk dua orang akan mencukupi tiga orang dan makanan untuk tiga orang akan mencukupi empat orang" (HR. Bukhari dan Muslim) 
Dalam hadits ini kata wasath bermakna posisi tengah, posisi yang selalu diberkahi Allah swt. Hal ini menujukkan bahwa umat Islam adalah umat terbaik karena selalu berada pada posisi tengah antara kecenderungan ekstrim pada dunia dan kecenderungan ekstrim pada akhirat sehingga melupakan dunia. Islam pada posisi tengah dalam hal ekstremisme kanan yang ghuluw (berlebihan) pada nilai-nilai ruhani dan ekstremisme kiri yang tidak peduli pada rohani. Islam memposisikan diri berada di tengah kedua ekstrimisme itu dengan penuh keadilan dan keseimbangan.

\section{Wasathiyah bermakna posisi terbaik seperti Harta terbaik adalah harta pertengahan}

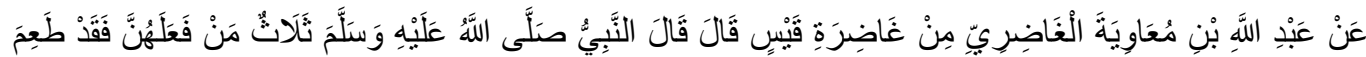

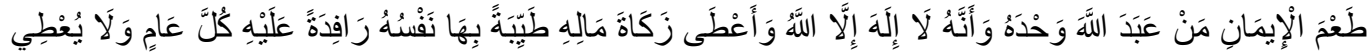

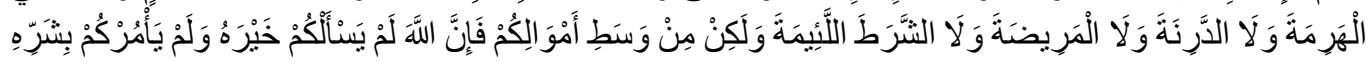

Dari Abdullah bin Muawiyah Al Ghadhiri ia berkata; Nabi saw bersabda: "Tiga perkara, barang siapa yang melaksanakannya maka ia akan merasakan nikmatnya iman yaitu barang siapa yang beribadah kepada Allah semata dan tidak ada tuhan yang berhak disembah kecuali Allah, dan menunaikan zakat hartanya dengan jiwa yang lapang dan jiwanya terdorong untuk menunaikan zakat setiap tahun dan tidak memberikan hewan yang sudah tua dan tanggal giginya, lemah, serta yang sakit atau menunaikannya dengan yang kecil jelek. Akan tetapi tunaikanlah dengan harta kalian yang pertengahan karena sesungguhnya Allah tidak meminta harta terbaik kalian dan tidak juga menyuruh kalian memberikan harta yang terburuk" (HR. Abu Daud. Hadits No 1349).

Hadits ini menjelaskn ajaran moderasi Islam dalam mengeluarkan zakat, bahwa harta yang dikeluarkan oleh seorang muslim dari kewajiban zakatnya adalah harta pertengahan antara harta yang paling mewah atau mahal dan harta yang paling murah dan rendah. Zakat terbaik adalah zakat dari harta yang halal dan mencukupi nishab serta haulnya serta harta yang telah mencukupi nafkah wajib bagi keluarga. Syari'at Islam tidak menerima zakat harta yang belum sesuai nishab dan haulnya, Islam tidak menerima harta yang yang buruk dan haram seperti hasil korupsi, riba dan najis. Zakat terbaik adalah harta yang digunakan sehari-hari oleh umat Islam yang produktif, oleh karenanya syari'at tidak membolehkan zakat perhiasan berupa emas dan perak yang dipakai sehari-hari, hewan ternak yang dipakai bekerja, rumah mewah yang menjadi tempat tinggal dan sebagainya, kecuali yang disimpan atau ditabung dan diinvestasikan. inilah maksud harta pertengahan.

\section{Wasathiyah Menurut Para Ulama dan Fuqaha}

Tidak lengkap rasanya bila tidak mengemukakkan secara khsusus pandangan Ulama Salaf dan Khalaf tentang wasathiyah ini, sehingga secara epistimologi wasathiyah atau moderasi Islam secara konsep dan definisi telah final dan tidak dapat ditolak oleh narasi apapun baiik berdasarkan nash-nash Islam maupun logika. Berikut adalah konsep dan pengertian wasathiyah (Moderasi) dalam pandangan para Ulama. 


\section{Imam Ibnu Jarir At-Thabari (W: 310H/923M) ${ }^{14}$.}

Imam Ibnu Jarir At-Thabari adalah Syaikhul mufassirin, beliau telah menulis tafsir bilma'tsur (berdasar riwayat) terlengkap di dunia pada abad ke 3 hijriah. Tafsirnya menjadi rujukan para ulama tafsir di masanya sampai saat ini. At-Thabari telah memeberi konsep wasathiyah yang lengkap dan mumpuni, saat manafsirkan surat Al-Baqarah ayat 143, sehingga menjadi referensi para ulama wasathiyah samapai saat ini.

At-Thabari berpendapat bahwa umat Islam yang wasathiyah adalah "Umat Islam adalah umat moderat, karena mereka berada pada posisi tengah dalam semua agama, mereka bukanlah kelompok yang ekstrem dan berlebihan seperti sikap ekstremnya nashrani dengan ajaran kerahibannya yang menolak dunia dan kodratnya sebagai manusia. Umat Islam juga bukan seperti bebasnya dan lalainya kaum yahudi yang mengganti kitab-kitab Allah, membunuh para Nabi, mendustai Tuhan dan kafir pada-Nya. Akan tetapi umat Islam adalah umat pertengahan dan seimbang dalam agama, maka karena inilah Allah menamakan mereka dengan umat moderat"15.

At-Thabari memposisikan umat Islam antara dua ajaran agama samawi yang telah mengalami penyelewengan dan distorsi yaitu yahudi dan nashrani. Yahudi adalah agama yang dianut oleh bani israil dipimpin oleh para rahib yang tidak memiliki konsistensi pada ajaran asli taurat, mereka merubah ajaran taurat sesuai dengan napsu mereka. Firman Allah: "Diantara orang Yahudi yang merubah firman Allah dari tempatnya, dan mereka berkata; kami mendengar tapi kami tidak mematuhinya" (QS. An-Nisa: 46).

Kaum Yahudi mengganti tuhan dan syari'at taurat yang diajarakan Allah lewat para Nabi-Nya kepada mereka, serta menganti Allah dengan Nabi Uzair dan individu lainnya sebagai anak tuhan. Allah berfirman: "Dan orang-orang Yahudi berkata: Uzair putra Allah, dan orang-orang nashrani berkata: Al-Masih putra Allah” (QS. AtTaubah: 30). Bahkkan Yahudi tega dan sadis membunuh para Nabi dan Rasul yang diutus oleh Allah kepada mereka untuk memperbaiki akidah dan kehidupan mereka. Oleh karena itulah mereka selamanya dihinakan, dilaknat dan dimurkai oleh Allah swt. Allah berfirman: "Kemudian mereka ditimpa kehinaan dan kemiskinan serta selalu mendapat kemurkaan dari Allah. Hal itu karena disebabkan mereka mengingkari ayat-

\footnotetext{
14 Imam Ibnu Jarir Ath-Thabari. Lahir tahun $838 \mathrm{M} / 224 \mathrm{H}$ dan wafat tahun $923 \mathrm{M} / 310 \mathrm{H}$ adalah seorang sejarawan, mufassir dan pemikir muslim. Lahir di daerah Amol atau Amuli, Thabaristan (sebelah selatan Laut Kaspia). Nama lengkapnya adalah Abu Ja'far Muhammad bin Jarir bin Yazid bin Katsir bin Ghalib al-Amali ath-Thabari, lebih dikenal sebagai Ibnu Jarir atau athThabari. Beliau adalah Ulama besar Islam yang menguasai banyak IImu dan karya besar dalam Islam. Di antara karyanya yang terkenal dalam IsImu sejarah adalah Tarikh ar-Rusul wa al-Muluk (Sejarah Para Nabi dan Raja) atau lebih dikenal sebagai Tarikh ath-Thabari. Karya beliau ini telah diterjemahkan ke dalam bahasa Inggris menjadi 40 jilid, berjudul The History of al-Tabari. Kitab ini berisi sejarah dunia hingga tahun $\underline{915}$, dan terkenal karena keakuratannya dalam menuliskan sejarah Arab dan Muslim. Dalam bidang Tafsir beliau dikenal dengan Syaiukhul Mufassirin dengan kitab Tafsir yang terkenal bernama Tafsir ath-Thabari, yang menjadi sumber dan rujukan para mufassir lainnya, seperti AlQrthubi, Al-Baghawi, as-Suyuthi dan juga Ibnu Katsir.
}

${ }^{15}$ Ibid, hal 8 
ayat Allah dan membunuh para Nabi tanpa alasan yang benar" (QS. Al-Baqarah: 61, Ali Imran: 21 dan 112 dan At-Taubah: 111).

Adapun agama dan umat Nashrani, mereka adalah umat yang kurang menggunakan akal sehat dalam beragama, mereka sangat tekstual dan kaku dalam memahami ajaran agamanya, nashrani adalah agama yang hanya memperhatikan masalah ukhrawi dan tidak memperdulikan masalah kehidupan dunia. Akibat pemahaman yang kaku dan tekstual ini mereka tidak menerima perubahan dan mejadikan hidup kerahiban (menjauhi dunia) sebagai ajaran agamanya padahal Allah tidak mengajarkan demikian. Allah berfirman: "Mereka mengada-adakan rahbaniyah (hidup kerahiban), padahal Kami tidak mengajarkannya kepada mereka, dan yang Kami wajibkan hanyalah mencari keridhaan Allah, tetapi mereka tidak pelihara sebagaimana mestinya". (QS. Al-Hadid: 27).

Itulah kehidupan dua umat yang tidak moderat dalam beragama, Yahudi terjerembab dalam jurang penyelewengan yang menyebabkan murka Allah yang abadi pada mereka, karena kelancangan dan sikap bebas mereka merubah ajaran Allah. Sementara kelompok nashrani yang tekstual, kaku serta ghuluw (ekstrem) dalam memperaktekan ajarana agama dalam bentuk kerahiban menolak dunia, menyebabkan mereka terperosok dalam jurang kesesatan abadi jauh dari hidayah Allah swt.

\section{Imam Abu Hamid Al-Ghazali (W: $505 H / 1111 M)^{16}$}

Diantara Ulama besar yang telah memperkenalkan prinsip-prinsip wasathiyah Islam adalah Imam Abu Hamid Al-Ghazali, beliau berpendapat dalam kayanya "Ihya Ulumiddin" ketika membahas sikap para Sahabat Nabi saw terhadap dunia pada Bab Zuhud, Al-Ghazali berkata: "bahwa para sahabat tidak bekerja di dunia untuk dunia tapi untuk agama, para sahabat tidak menerima dan menolak dunia secara keseluruhan atau secara mutlak. Sehingga mereka tidak ekstrem dalam menolak dan menerima, tapi mereka bersikap antara keduanya secara seimbang, itulah keadilan dan pertengahan antara dua sisi yang berbeda dan inilah sikap yang paling dicintai oleh Allah swt"17.

Al-Ghazali melihat bahwa kehidupan ideal dalam mengaktualisasikan ajaran Islam adalah dengan jalan pertengahan, seimbang dan adil atau proporsional antara

16 Abu Hamid Muhammad bin Muhammad al Ghazali ath-Thusi asy-Syafi'i. Iahir di kota Thus tahun $1058 \mathrm{M} / 450 \mathrm{H}$ dan wafat di kota Thus tahun: $1111 \mathrm{M} / 505 \mathrm{H}$ dalam usia antara 52-53 tahun. Beliau adalah seorang filsuf, teolog dan salah seorang Ulama fiqh muslim yang dikenal sebagai Algazel di dunia Barat abad pertengahan. Imam al-Ghazali mempunyai daya ingat yang kuat dan bijak berhujjah, sehingga la digelar Hujjatul Islam karena kemampuannya tersebut. la sangat dihormati di dua dunia Islam, khususnya di masa dinasti Saljuk dan Abbasiyah yang merupakan pusat kebesaran dan kejayaan Islam saat itu. Al-Ghazali menguasai pelbagai bidang ilmu pengetahuan, diantara Ilmu Filsafat, Fiqh, Teologi (Ushul Ad-Din) Tasawuf, Maqashid Syari'ah, sastera dan sebagainya. Al-Ghazali dilantik menjadi mahaguru di Madrasah Nizhamiyah (sebuah universitas yang didirikan oleh perdana menteri) di Baghdad pada tahun 484 Hijriah. Kemudian dia dilantik pula sebagai Naib Kanselor di sana. Al-Ghazali mengembara ke beberapa tempat di dunia, seperti Mekkah, Madinah, Mesir dan Jerusalem untuk berjumpa dengan ulama-ulama untuk mendalami ilmu pengetahuannya yang ada. Dalam pengembaraan, dia menulis kitab Ihya Ulumuddin yang memberi sumbangan besar kepada masyarakat dan pemikiran manusia dalam semua masalah.

17 Abu Hamid Al-Ghazali, Ihya Ulumiddin, vol 2, (Kairo: Al-Maktabah A-taufiqiyah, 2003), hal 
dunia dan akhirat, antara rohani dan jasmani dan antara materi dan spiritual. Walaupun Al-Ghazali dikenal dengan pandangan tasaufnya dan kehidupan zuhudnya, namun beliau tetap mengakui dan meyakini bahwa manhaj hidup yang paling sempurna dan sesuai dengan hakikat ajaran Islam berdasarkan Al-Qur'an dan As-Sunnah serta model hidup para Salaf shaleh adalah arah wasathi (moderat) bukan manhaj ghuluw (ekstrem) atau ta'thil (meninggal) ajaran Islam.

Pada pembahasan tentang Uzlah (mengasingkan diri dari manusia untuk ibadah) Al-Ghazali membahas sangat luas dan mendalam antara keutaman uzlah dan berinteraksi dengan manusia?. Ternyata Al-Ghazali walaupun beliau banyak menyampaikan manfaat uzlah dalam kehidupan para hamba berdasarkan banyak ayat dan hadits Nabi saw, tapi beliau tetap berpendapat dengan manhaj moderat dan pertengahan serta seimbang antara memutuskan uzlah dan berdakwah serta menuntut Ilmu. Al-Ghazali berkata: “Amar ma'ruf Nahi munkar" adalah salah satu dasar agama, hukumnya adalah wajib. Karenanya barang siapa yang berinteraksi dengan manusia pasti dia akan menyaksikan kemungkaran dan bila dia diam atas kemungkaran itu, maka dia berdosa dan durhaka pada Allah swt ${ }^{18}$.

Dalam masalah belajar dan mengajar Al-Ghazali melihat bahwa seorang muslim harus dan wajib belajar dan mengajar bahwa keduanya adalah salah satu ibadah yang paling besar di dunia dan keduanya tidak bisa dilakukan kecuali berinteraksi dengan manusia. Barang siapa yang dirinya belum berilmu dan butuh belajar dan ilmu, maka baginya haram beruzlah, sebaliknya bila dia telah berilmu dan mengetahui halhal wajib dalam agama, serta melohat bahwa dia membutuhkan focus dalam ibadah, maka dia boleh beruzlah"19

\section{Imam Al-Qurthubiy (W: 671H/1273M) ${ }^{20}$}

Seorang ulama tafsir yang sangat dikenal dengan tafsirnya yang sangat terkenal dalam dunia Islam sejak abad 7 (tujuh) Hijriah “Al-Jami' Liahkam Al-Qur'an”, Imam Muhammad bin Ahmad Al-Anshari Al-Qurthubiy. Bahwa umat wasathan adalah umat yang berkeadilan dan paling baik karena sesuatu yang paling baik adalah yang paling adil"21. Al-Qurthubi menjelaskan bahwa Allah swt menginginkan umat Islam menjadi umat yang moderat, paling adil dan paling cerdas. Bahwa umat Islam harus menjadi

18 Lihat Abu Hamid Al-Ghzali, Ihya Ulumuddin, vol 2, hal 326

19 Ibid, hal 336

20 Al-Qurthubi atau Qurtubi adalah seorang ulama besar muslim, Imam, Ahli hadits, dan seorang mufassir Al-Qur'an yang terkenal. Nama lengkapnya adalah "Abu 'Abdullah Muhammad bin Ahmad bin Abu Bakr Al-Anshari al-Qurthubi". Al-Qurthubi berasal dari Qurthub (Cordoba, Spanyol) dan mengikuti mahzab fiqih Maliki. Karya Imam Qurthubi yang paling terkenal adalah sebuah tafsir AlQur'an yang diberinya judul “Al-Jami' liahkam al-Qur'an wa al-Mubayyin Lima Tadhammanahu Min asSunnah wa Ayi al-Furqan" atau yang lebih dikenal sebagai Tafsir Qurthubi saja. Kitab ini tergolong besar yang terdiri hingga 20 jilid. Kitab tafsir ini merupakan salah satu tafsir terbesar dan terbanyak manfaatnya dalam sejarah Islam. Diantara kitab tafsir yang merujuk pada tafsir Al-Qurtubi adalah Tafsir Ibnu katsir, Tafsir Al-Bahru Al-Muhith dan tafsit fathul qadir. Imam Qurthubi meninggal dunia dan dimakamkan di Mesir, pada Senin, 09 Syawal tahun $671 \mathrm{H}$.

21 Al-Quthubi, Al-Jami' Li Ahkam Al-Quran (Tafsir Al-Qurthubi), vol 1, hal 477 
umat yang selalu pada posisi pertengahan dan moderat tidak pada posisi ekstrem atau berlebihan",22.

\section{Imam Ibnu Taimiyah (W: $728 H / 1328 M)^{23}$}

Imam Ibnu Taimiyah adalah seorang Ulama besar abad 7 (tujuh) hijriah, dikenal sangat tegas dan ketat berpegang teguh pada Al-Qur'an dan As-Sunna. Beliau sangat keras dan tegas memerangi bid'ah juga menyatakan bahwa arah pemikiran Islam wasathiy (moderat), tetap sebagai arah pemahaman dan pemikiran Islam yang paling baik dan tepat. Ibnu Taimiyah berpendapat bahwa "Umat Islam disebut umat wasath karena mereka tidak berlebihan dan ekstrem terhadap nabi-nabi mereka. Umat Islam moderat tidak menyamakan para Nabi tersebut sebagai Tuhan dan menjadikan sifat para nabi sebagai sifat ketuhanan, lalu menyembahnya dan menjadikan mereka penyembuh penyakit. Umat Islam juga tidak mengabaikan para Nabi itu sebagai utusan Allah, menolak mereka dan tidak mentaati mereka, tapi umat Islam menghormati para Nabi, mengikuti syari'at mereka dan menolong agama mereka"24.

Ibnu Taimiyah berpendapat bahwa wasathiyah umat ini terletak pada masalah kebersihan dan najis, pada masalah halal dan haram dan masalah akhlak atau moralitas. Tidak pernah terjadi ajaran Islam menjadi keras dan kaku pada masa generasi salaf dan tidak pernah terjadi sikap memudah-mudahkan Islam pada masa generasi khalaf, karenanya hanya musuh Allah yang menjadikan agama ini menjadi ekstrim dan hanya para wali Allah yang menjadikan agama ini penuh rahmat dan kasih sayang"25. Bahkan Ibnu Taimiyah berpendapat bahwa siapa saja yang keluar atau keras melanggar terhadap hal-hal yang pertengahan pada diri seseorang, maka dia telah melakukan pekerjaan bid'ah jahiliyah" 26 .

22 Ibid, vol 10, hal 538

23 Abul Abbas Taqiyuddin Ahmad bin Abdus Salam bin Abdullah bin Taimiyah Al-Harrani. lahir tahun: $661 \underline{H} / \underline{1263} \mathrm{M})$ dan wafat tahun: $728 \mathrm{H} / \underline{1328} \mathrm{M})$, beliau berasal dari Kota Harran, Turki. Nama beliau lebih dikenal dengan sebutan Ibnu Taimiyah, beliau adalah seorang pemikir Islam dan ulama Islam ahli dalam Bahasa Arab, Fiqh, Ushul Ad-Din, IIm Tafsir, IImu Hadits dan sebagainya. Ibnu Taimiyah lahir di zaman ketika Baghdad merupakan pusat kekuasaan dan budaya Islam pada masa Dinasti Abbasiyah. Beliau adalah orang yang kuat pendiriannya dan teguh berpijak pada garisgaris yang telah ditentukan Allah, mengikuti segala perintah-Nya dan menjauhi segala larangan-Nya. Ibnu Taimiyah pernah memimpin sebuah pasukan untuk melawan pasukan Mongol di Syakhab, dekat kota Damaskus, pada tahun 1299 masehi dan dia mendapat kemenangan yang gemilang. Pada Februari 1313, memimpin pertempuran di kota Jerussalem dan mendapat kemenangan dan tetap meneruskan karirnya sebagai guru besar di madrasah-madrasah dan universitas di masa itu. Ibnu Taymiyyah amat menguasai ilmu rijalul hadits (perawi hadits) yang berguna dalam menelusuri Hadits dari periwayat atau pembawanya dan Fununul hadits (macam-macam hadits) baik yang lemah, cacat atau shahih. la memahami semua hadits yang termuat dalam Kutubus Sittah dan Al-Musnad. Dalam mengemukakan ayat-ayat sebagai hujjah (dalil), ia memiliki kehebatan yang luar biasa, sehingga mampu mengemukakan kesalahan dan kelemahan para mufassir atau ahli tafsir. Karaya banyak sekalia diantaranya, "As-Siyasah Syar'iyah”, “Aqidah Wasathiyah” dan sebagainya. Beliau yang terkenal dalam semua Ilmu Islam adalah "Majmu' Fatawa Ibnu Taimiyah".

24 Yusuf Al-Qardhawi, Fiqh Al-Wasathiyah Wa at-tajdid, hal 64

25 Lihat Ibnu Taimiyah, Majmu'ah Al-Fatawa Li Syaikhil Islam Ahmad bin Taimiyah, vol 28, (AlManshurah: Daar Al-Wafa, cet-3, 2005), hal 613

26 Ibid, vol 28, hal 14 


\section{Imam As-Syathibiy (W: $790 \mathrm{H} / \mathbf{1 3 8 8 M})^{27}$}

Salah satu Ulama maqashid terbesar dalam Islam adalah Imam As-Syathibiy, beliau menjelaskan tentang wasathiyah atau manhaj moderasi adalah karakter utama syariah Islam, tidak ada ajaran dan nilai-nilai syari'ah yang tidak mengandung prinsip moderat dan tujuan yang moderat. Moderasi adalah standar syari'ah dan oleh karenanya setiap ijtihad dan fatwa terkait dnegan syari'at harus diwarnai prisnsip moderasi atau wasathiy. Dalam kitabnya "Al-Muwafaqaat” As-Syatibi berkata: "Bahwa kandungan syari'at berjalan pada jalan pertengahan yang paling adil, berada pada posisi yang seimbang antara dua kutub yang bertentangan, tanpa cenderung pada salah satunya. Berada pada kemampuan hamba yang tidak menyulitkan dan meremehkan, akan tetapi syari'at berada pada pembebanan mukallaf dengan ukuran yang seimbang dan sangat adil, seperti Ibadah shalat, zakat, haji, jihad dan lainnya"28. Bahkan Imam As-Syatibi berkata: "Bila seandainya penetapan hukum syara' terdapat kecenderungan keluar dan menyeleweng dari manhaj moderat, kepada salah satu dari dua kutub yang saling bertentangan, yaitu kutub ekstrim kanan dan ekstrim kiri, maka penetapan hukum atau fatwa, segera dikembalikan kepada karakternya atau manhajnya yang moderat"29.

Jadi menurut As-Syatibi kewajiban mengikuti manhaj moderat bukan sekedar mengikuti secara pasif berdasarkan dalil-dalil dari nash-nash Al-Qur'an dan AsSunnah, akan tetapi wasathiyah adalah standar dan patron abadi dan bersifat tetap serta mutlak, sehingga kapan terjadi penyelewengan fatwa atau ijtihad fiqhiyah terkait syari'at Islam dalam kasus-kasus atau produk-produk hukum Islam, maka harus dikembalikan pada sifat dan karakternya yang wasathiy atau moderat.

\section{Syekh Muhammad Rasyid Ridha (W: 1935M) ${ }^{30}$}

27 Abu Ishaq asy-Syathibi Wafat tahun: $790 \mathrm{H} / 1388 \mathrm{M}$, lahirnya tidak diketahui. Nama lengkapnya adalah Abu Ishaq Ibrahim bin Musa bin Muhammad Al-Lakhmi Asy-Syathibi, berasal dari kota Xativa yang kemudian ia dikenal dengan julukan Imam Syathibi (Imam dari Xativa). Sedangkan keluarganya merupakan migran keturunan bangsa Arab-Yaman dari Banu Lakhm yang berasal dari Betlehem, Syam. As-Syatibi adalah imam ahlussunnah dari mazhab Maliki yang hidup pada masa Spanyol Islam. As-Syatibi adalah Ulama Islam Besar khususnya dalam bidang Fiqh dan Ushulul Fiqh, beliau sangat dikenal dengan bapak Mawashid Syari'ah. Karya-karya beliau yang sangat fenomenal dalam Ilmu-ilmu Fiqh dan Ushl Fiqh diantaranya adalah: Al-Muwafaqat, yang aslinya berjudul Unwan At-Ta'rif bi Ushul At-Taklif sebuah kitab tentang ilmu ushul figh yang menerangkan tentang hikmah-hikmah di balik hukum taklif. Al-l'tisham, kitab yang menerangkan tentang bid'ah dan seluk beluknya, Al-Majalis, kitab fiqh yang merupakan syarah dari Kitabul Buyu' (Kitab jual beli) yang terdapat dalam Shahih al-Bukhari, dan Al-Ifadat wa al-Insyadat.

28 Abu Ishaq As-Syatibi, Al-Muwafaqat fii Ushul As-Syariah, vol 2, (Kairo: al- maktabah attaufiqiyah, 2003), hal 139

29 Ibid, hal 139

${ }^{30}$ Muhammad Rasyid bin Ali Ridha bin Syamsuddin bin Baha'uddin Al-Qalmuni Al-Husaini. lahir tahun: $1865 \mathrm{M}$ dan wafat tahun: 1935M, dikenal dengan nama Rasyid Ridha. Beliau adalah seorang intelektual muslim asal Suriah yang mengembangkan gagasan modernisme Islam yang awalnya digagas oleh Jamaluddin Al-Afghani dan Muhammad Abduh. Ridha mempelajari kelemahan-kelemahan masyarakat muslim saat itu, dibandingkan masyarakat kolonialis Barat, dan menyimpulkan bahwa kelemahan tersebut antara lain kecenderungan umat untuk mengikuti tradisi secara buta (taqlid), minat yang berlebihan terhadap dunia sufi dan kemandegan pemikiran ulama yang mengakibatkan timbulnya kegagalan dalam mencapai kemajuan di bidang sains dan teknologi. Ridha berpendapat bahwa 
Pemikir dan cendikiawan Islam modern yang karya dan pandangan-pandangan serta pemikirannya sangat berpengaruh dalam dunia Islam, baik salam akidah, syariah dan social adalah Syekh Muhammad Rasyid Ridha. Ridha berpendapata bahwa Islam bukan agama yang hanya focus pada rohani, bukan pula pada jasmani, tapi Islam agama ruhani dan jasmani sekaligus, secara seimbang, moderat dan integral. Dalam Tafsirnya "Al-Manar", saat menafsir surat Al-Baqarah: 143 berkata: "Adapun umat Islam adalah umat yang Allah telah himpunkan di dalamnya dua dimensi, yaitu; ruh dan jasad. Maka umat Islam adalah umat ruhani dan jasmani. Karenanya umat Islam adalah umat yang diberikan semua dimensi kemanusiaan, karena manusia terdiri dari rohani dan jasmani. Saat Allah swt berfirman: "Demikian Kami jadikan kalian umat yang pertengahan" (QS. Al-Baqarah: 143) ini menujukkan bahwa kalian umat Islam mengetahui dua unsur manusia dan kalian memiliki dua kesempurnaan ini, agar kalian menjadi saksi bagi manusia seluruhnya.

Ridha berkata bahwa kelompok pemuja jasad hanya memperhatikan masalah fisik dan meninggakan ruhani atau bathin, sementara kelompok ruhani sangat ekstrem menyakini ruh manusia dan meninggalkan dunia. Kelompok pertama berkata "Tidak ada kehidupan kecuali hidup kita di dunia ini, kita mati mati dan hidup, dan tidak ada yang mematikan kita kecuali waktu" (QS. Al-Jatsiyah: 24). Kelompok ini sama dengan hewan dan mereka menolak semua keistimewaan ruhani. Sementara kelompok yang ekstrem pada agama, mereka berkata: "Sesungguhnya kehidupan dunia ini adalah penjara bagi ruh dan hukuman baginya, maka kita harus membebaskan diri kita dari dunia dengan cara meniggalkan semua nikmat jasmani dan menyiksanya, menghancurkan semua hak-hak napsu dan melepaskannya dari semua yang llah berikan di dunia ini. Kalian menyaksikan bagaimana dua kelompok telah keluar dari sikap adil dan seimbang" 31 .

Rasyid Ridha adalah pemikir Islam yang sangat berani mengkritik kaum sufi di mesir, yang sebagian besar ajarannya focus pada penyucian rohani dan pembangunan spiritual yang berlebihan, sehingga melupakan pembangunan fisik, keterampilan, kecerdasan dan kebangkitan umat lewat teknologi. Rasyid Ridha sangat vocal mengkritisi praktek keagamaan yang parsial ini, dan mengajaknya menuju Islam yang

\footnotetext{
kelemahan ini dapat diatasi dengan kembali ke prinsip-prinsip dasar Islam dan melakukan ijtihad dalam menghadapi realita modern. Mulai tahun 1898 hingga wafat tahun 1935, Ridha menerbitkan surat kabar yang bernama "Al-Manar". Dalam bidang agama, Rasyid Ridha berpendapat umat Islam lemah dikarenakan tidak lagi mengamalkan ajaran agama yang murni seperti yang diterapkan pada masa Rasulullah SAW. Sebab, ajaran pada saat itu sudah tercampur bid'ah dan khurafat. Rasyid Ridha juga menegaskan, jika umat Islam ingin maju, mereka harus kembali berpegang teguh kepada Al-Qur'an dan Sunnah Rasulullah SAW tanpa terikat oleh pendapat-pendapat ulama terdahulu yang tidak sesuai dengan tuntutan hidup modern. la kemudian mengamati paham fatalisme yang menyelimuti umat Islam pada waktu itu. Rasyid Ridha berpendapat ajaran Islam itu seharusnya mengandung paham dinamika, bukan fatalisme. Idenya yang lain ialah toleransi dalam bermazhab. Menurutnya, timbulnya perpecahan pada kalangan umat Islam dikarenakan adanya sikap fanatisme terhadap mazhab. Oleh karena itu, menurut Rasyid Ridha perlu menghidupkan toleransi dalam bermazhab. Bahkan, termasuk dalam bidang hukum, walaupun ia sendiri dikenal sebagai pengikut Mazhab Hanbali. Karya beliau yang sangat terkenal dalam dunia Islam adalah karya beliau dalam bidang Tafsir Al-Qur'an yang berjudul "Tafsir Al-Manar".

31 Yusuf Al-Qardhawi, Fiqh Al-Wasathiyah Wa at-tajdid, hal 76
} 
sempurna dan moderat. Islam menurutya adalah agama akal sehat, ruhani dan jasmani sekaligus, Islam harus berdasarkan Al-Qur'an dan As-Sunnah bukan syahwat dan perasaan serta pengalaman-pengalaman spiritual belaka, sehingga membawa kehidupan umat yang timpang dan jauh dari Al-Qur'an dan As-Sunnah yang menyebabkan mundurnya Islam dan umatnya.

\section{Al-Imam Hasan Al-Banna (W: 1368H/1949) ${ }^{32}$.}

Imam Hasan Al-Banna adalah seorang ulama yang zuhud, alim dan organisatoris ulung di zamannya. Beliau sangat mumpuni dalam memahami kandungan Al-Qur'an dan Al-hadits, sehingga beliau meyakini bahwa Islam adalah agama yang dinantikan dan menyelamatkan dunia dan kemanusiaan. Oleh karenanya dalam pandangan Al-Banna', umat Islam memiliki ideologi dan pemikiran yang paling kuat di dunia ini, karena umat Islam memiliki dan mendakwahkan syari'ah Al-Qur'an yang paling adil dan moderat di dunia" 33 .

Dalam tulisannya yang berjudul "Dialektika Dakwah kita di Era Baru". AlBanna' mengkritik peradaban barat yang sangat materialisme, liberal yang tidak moderat yang sebenarnya menyimpang dari nilai-nilai kemanusiaan. Al-banna' meyakini bahwa ajaran dan perdaban Islamlah yang paling sempurna dan moderat, sesuai dengan fitrah mansuia, beliau berkata: "Pada fase ini manusia materialis menolak eksistensi ketuhanan dan semua yang terkait dengannya, mengingkari kenabian dan semua yang berhubungan dengannya. Mereka menolak keberadaan alam akhirat, balasan amal dan alam ruh dengan segala materinya. Barat materialisme hanya mengakui alam dunia yang rendah dan terbatas ini dan mereka manfsirkan semua

32 Imam Hasan bin Ahmad Abdurrahman Al-Banna adalah salah satu Ulama pembaharu Islam abad 20 asal mesir. Bahkan beliau disebut sebagai bapak pergerakan Islam modern yang pemikiran dan gerakan dakwahnya sampai saat ini menjadi rujukan para aktivis Islam dunia. Al-Banna lahir di propinsi Buhairah Mesir tahun 1907M, ayahnya adalah salah seorang Ulama yang konsen dengan Ilmu hadits. Al-Banna telah hapal Al-Qur'an sebelum usia 14 tahun, setelah menyelesaikan studi Sekolah Dasar dan Menengah di madrasah Ar-Rasyad dan Muhammadiyah, beliau telah aktif berdakwah dan mendirikan Organisasi Islam yang bernama Al-Akhlak Al-Adabiyah yang beranggotakan teman-teman sekolahnya. Beliau pernah mengikuti Thariqat Al-Hashafiyah yang mengajarkan kezuhudan, kesucian jiwa dan konsistensi. Saat belajar di Daarul Muallimin Damanhur tahun 1920, beliau telah ikut gerakan Nasional melawan penjajah, lalu tahun 1923 beliau pindah ke Kairo dan melanjutkan studi di darul Ulum. Saat kuliah ini beliau banyak berdiskusi dengan Ulama-ulama Al-Azhar tentang kondisi umat Islam dan mengajak mereka untuk melakukan amal Islam dengan semua sarana saat itu. Setelah lulus dari Darul Ulum tahun 1927 beliau diangkat menjadi guru di Ismailiyah deareh Kanal Swis, sambil berdakwah di kafe-kafe dan warung-warung makan di sana. Pada bulan maret tahun 1928 beliau bersama 6 orang temannya mendirikan Jama'ah Ikhwan Al-Muslimin. Jama'ah ini mengajak umat kembali kepada orisinalitas Islam, menghindari khilafiyah yang marak di masa itu dan focus pada pembinaan kaderkader dakwah. Tahun 1932 Al-Banna memindahkan markaz Ikhwan Muslimin ke Kairo, sehingga gerakan dakwah ikhwan ini menyebar keseluruh mesir. Setelah menerbitkan Majalah "Al-Ikhwan AlMuslimun" dan "An-Nadzir", Al-Banna berusaha agar dakwahnya tidak hanya di dalam mesir tapi sampai di luar Mesir, termasuk memperjuagkan kemerdekaan palestina dan Negara-negara Islam yang masih terjajah termasuk Indonesia saat itu. Pada tahun 1948 seluruh pimpinan Ikhwan Muslimin ditangkap oleh Raja Faruk dan Imam Hasan Al-Banna Syahid terbunuh oleh kerajaan. Dakwah Imam Hasan Al-Banna yang dikenal sangat orisinil karna berdasarkan Al-Qu'an dan As-Sunnah serta bersifat moderat dan komprehensip dalam semua aspek kehidupan manusia ini, menjadikannya dapat diterima oleh banyak Ulama di Negara-negara Islam hingga saat ini.

33 Hasan Al-Banna', Majmu'ah Ar-Rsail, (Kairo: Daar At_tauzi' wa An-Nasyr Al-Islamiy, 1992), hal 109 
fenomenanya berdasarkan kaidah-kaidah materialisme murni. Pemikiran materialisme di atas merupakan kesalahan yang nyata dan fatal dan merupakan sikap yang ekstrem. Pemikiran barat materialism menjadi bukti kebodohan manusia tentang segala sesuatu yang ada disekitarnya.

Hasan Al-Banna' lalu membandingkan peradaban barat materialisme dan ekstrem ini dengan ajaran Islam berkata: "Ajaran Islam yang lurus telah menjelaskan hal ini dengan benar. Islam mengakui eksistensi alam ruh dan menjelaskan hubungan yang terjalin antara manusia dengan Allah, Tuhan seluruh makhluk dan hubungannya dengan kehidupan alam akhirat yang akan dialami pasca kehidupan dunia. Islam juga mengakui kelebihan yang ada pada alam materi ini dengan segala manfaat yang dapat dirasakan oleh manusia jika mereka memakmurkannya dengan benar, dan menggunakannya dalam batas-batas kebaikan"34.

Hasan Al-Banna' paham betul dan meyakini bahwa Islam adalah agama sempurna, integral dan komprehensif. Hampir sama dengan Muhammad Rasyid Ridha, Hasan Al-Banna memahami bahwa Islam mengatur hidup manusia di dunia dan akhirat. Adalah sangat keliru orang yang memahami bahwa Islam hanya mengurus masalah ibadah dan rohani atau spiritual semata. Padahal Islam, menurut Al-Banna adalah akidah dan ibadah, tanah air dan warga Negara, agama dan Negara, spiritual dan dan kerja serta mushaf dan pedang" 35 . Ketika membahas tentang rukun pemahaman Islam, beliau berkata: "bahwa Islam adalah system yang sempurna yang meliputi semua dimensi kehidupan manusia; dia adalah Negara dan tanah air, pemerintah dan rakyat, akhlak dan kekuatan atau rahmat dan keadilan. Islam adalah tsaqafah (budaya) dan dan perundang-undangan, dia adalah materi dan harta kekayaan atau usaha dan kekayaan. Islam adalah Jihad dan dakwah atau tentara dan pemikiran, sebagaimana Islam adalah akidah yang jujur dan ibadah yang benar" ${ }^{36}$.

\title{
8. Al- Imam Muhammad Abu Zahrah (W: 1974M) ${ }^{37}$.
}

Imam Muhammad Abu Zahrah adalah salah satu ulama besar Islam zaman modern yang sangat mumpuni memahami dan menjiwai Islam, sehingga para Ulama di

\author{
34 Ibid, hal 228 \\ 35 Ibid, hal 119 \\ 36 Ibid, hal 356 \\ 37 Imam Muhammad Ahmad Musthafa Abu Zahrah lahir tahun 1894M di kota Mahallah Mesir.
} Abu Zahrah telah hapal Al-Qur'an pada usia sebelum 9 tahun dan belajar agama dengan orang tuanya yang juga alim dan wali Allah di zamannya, yaitu Syekh Musthafa Abu Zahrah. Keluarga ini adalah keluarga yang kuat beragama dan memiliki akhlak yang mulia dan hidup sederhana. Tahun 1913M, Abu Zahrah masuk Universitas Al-Ahmadi di Thanta, lalu masuk jurusan peradilan pada tahun 1916 dan menjadi mahasiswa terbaik. Beliau dinobatkan menjadi Guru Besar di Al-Azhar dengan keahlian dalam Ilmu Syari'ah, tafsir, sejarah Islam dan pemikiran Islam. Pada tahun 1963M pernah menjadi dekan fakultas Syari'ah di Universitas Liga Arab Mesir. Abu Zahrah pernah menjadi anggota Majma'al Buhuts Al-Islamiyah di Al-Azhar, ketua Kajian Al-Qur'an dan As-Sunnah, beliau adalah Syaikh dalam kajian mazhab Abu Hanifah dan Mazhab Syafi'iy. Abu Zahrah memiliki kecerdasan luar biasa, ketajaman argumentasi, kekuatan hapalan dan kemampuan berbicara. Abu Zahrah adalah pengisi seminar dan penulis yang luar biasa, baik nasional maupun internasional. Karya tulis IImiah beliau dalam Islam mencapai ratusan judul diantaranya; Ushul Fiqh, Al-Khitabah, Riba dalam Islam, Ekonomi Islam, Landasan Fiqh Ja'fari, Syafi'iy, Maliki, Hanbali, Hanafi. Akidah Islamiyah, Figh Islam, Biografi Ulama-ulam besar Islam seperti Malik, Syafi'iy, Hanbali, Hanafi, Ibnu taimiyah, Ibnu Hazm dan lain-lain. 
zamannya menyebutnya sebagai syekhnya para Ulama di masanya. Sampai saat ini para Ulama Islam dan para cendikiawan Islam dunia selalu merujuk pada pendapat Abu Zahrah dalam berbagai masalah agama, seperti Fiqh, Ijtihad, teologi, pemikiran Islam dan sebagainya. Menurut Abu Zahrah (sebutan yang sering dipakai untuk Imam Muhammad Abu Zahrah), umat ini adalah umat yang meneladani Nabinya, yaitu Muhammad saw dalam hal kelapangan dada dan toleransi. Demikian pula Islam adalah agama moderat, pertengan dan terbaik.

Abu Zahrah ketika menafsirkan surat Al-Baqarah, ayat: 143 berkata: "kata wasatahan pada ayat ini memiliki dua makna. Pertama: Sesuatu yang pertegahan antara dua hal yang bertentangan. Kedua: bermakna kebaikan dan keunggulan. Islam adalah agama pertengahan atau moderat yang berada pada posisi berlebihan atau ekstrem dan posisi mengurangi atau melalaikan. Islam adalah pertengahan antara sikap Yahudi dan Nashrani. Agama Yahudi telah durhaka dan lalai terhadap kewajiban mereka teradap para Nabi, sehingga mereka membunuh para Nabi. Agama Nashrani bersikap sebaliknya, mereka ekstrem dalam menghormati dan mensucikan Nabi, sehingga mereka menyembahnya dan menjadikannya Tuhan. Karenanya manhaj atau arah keagamaan yang pertengahan atau moderat adalah tidak ekstrem dan tidak pula memudah-mudahkan atau meninggalkan"38.

\section{Al-Imam Al-Akbar Mahmud Syalthut (W:1893H/1963M) ${ }^{39}$}

Beliau adalah Ulama besar Islam asal Mesir, Syeikhul Al-Azhar, pemilik karya yang sangat dikenal dalam keilmuan Islam yang berjudul "Al-Islam Akidah wa Syari'ah". Syalthut berpendapat bahwa Islam adalah agama moderat karea dia terdiri dari akidah dan syari'ah yaitu agama yang mengandung unsur teori dan implementasi serta aktualisasi. Akidah adalah ajaran yang bersifat teori, abstrak dan keimanan, sementara syari'ah adalah ajaran yang bersifat praktek (amaliy) yang mengaktualisasikan teori, konsep dan keimanan dalam kehidupan manusia sehari-hari.

Syalthut berkata: “Akidah adalah dimensi teori yang menuntut keimanan dan keyakinan padanya sebelum hal-hal yang lainnya, yang membutuhkan keyakinan tanpa keraguan, karakter akidah adalah berdasarkan nash-nash Al-Qur'an yang pasti dan

38 Muhammad Abu Zahrah, Zahrah At-Tafasir, (Daar Al-Fikr Al-Arabiy, 187), hal 438

${ }^{39}$ Syekh Mahmud Syaltut lahir pada tahun 1310 H. di Buhairah, Mesir. Setelah menyelesaikan pendidikannya di Universitas Iskandaria Mesir, beliau mengajar di Universitas tersebut lalu pindah ke Universitas Al-Azhar. Di sana beliau terus berkembang dan maju hingga pada akhirnya pada tahun $1378 \mathrm{H}$ beliau menjadi mufti umum Al-Azhar. Beliau terus mengemban tanggung-jawab ini hingga wafat pada tahun $1383 \mathrm{H}$. Syekh Mahmud Syaltut adalah seorang ulama, ahli tafsir dan mufti. Beliau juga dikenal sebagai penyeru persatuan umat Islam. Sebelum dikenal sebagai pemikir dan teolog besar, beliau sudah dikenal sebagai seorang fakih dan pelopor pendekatan antar mazhab Islam. Beliau menjadi wakil rektor Universitas Al-Azhar tersebut pada tahun 1957M. Pada bulan Oktober tahun 1958M beliau diangkat menjadi rektor universitas oleh presiden. Beliau mengemban tanggung-jawab ini hingga akhir hayatnya. Pemimpin besar dan cendekiawan ini wafat pada umurnya yang ke 70 di malam Jum'at tanggal 26 Rajab tahun $1383 \mathrm{H}$ yang bertepatan dengan tanggal 12 September 1963M. Hasil karya beliau yang populer antara lain: Tafsir Al-Qur'an Al-Karim Nahju Al-Qur'an fi Bina Al-mujtama' Al-Islam, AlAqidah wa Al-Syariah, Al-FatawaAl-Qital fiAl-Islam, Min Tawjihat Al-Islam, Muqaronah Al-Madzahib fi Al-Fiqh, Fiqh Al-Qur'an. Karyanya yang sangat terkenal dalam ilmu Syariah adalah "Al-Islam Aqidah wasyari'ah". 
Ijma' Ulama yang disepakati, dia adalah awal dari semua misi dakwah para Nabi dan Rasul. Sementara syari'ah adalah system yang Allah swt syari'atkan atau yang Allah tetapkan dasar-dasarnya agar manusia menjadikannya sebagai landasan dalam berinteraksi pada Allah swt, landasan hubungan dan interaksi dengan saudaranya sesama muslim, intekasi kepada saudaranya sesama manusia dan interaksi kepada alam semesta dan kehidupan ini. Karenanya Allah swt selalu menyebut akidah dengan iman dan syari'at ini dengan amal shaleh. Seperti firman Allah "Sesungguhnya orang-orang yang beriman dan beramal shaleh, maka mereka akan tinggal di surga firdaus" (QS. AlKahfi: 107) dan ayat-ayat lainnya"40.

\section{Syekh Yusuf Al-Qardhawi dan gerakan Moderasi Islam}

Syekh Yusuf Al-Qardhawi lahir di desa Shift Turab, Propinsi Al-Gharbiyah, Mesir tahun 1926M. Al-Qardhawi kecil yatim namun cerdas ini dimasukkan pamannya di salah satu kuttab di desanya. Qardhawi telah hafal Al-Qur'an dan menguasai tajwidnya sebelum usia 10 tahun. Dari kuttab beliau melanjutkan studinya di madrasah tsanawiyah dan Aliyah Al-Azhar dan selalu juara kelas. Diantara gurunya ada yang memanggilnya "wahai Ulama". Tahun 1953 beliau lulus sarjana Fakultas Ushuluddin Al-Azhar. Tahun 1958M lulus pra-magister (Diploma) fakultas Adab Al-Azhar dan tahun 1960M lulus magister Ulumul Qur'an fakultas Ushuluddin Al-Azhar. Pada tahun 1973M, Al-Qardhawi lulus Doktoral dengan nilai Summa Cumlaude pada fakultas yang sama dengan disertasi "Zakat dan pengaruhnya teradap kehidupan sosial". Disertsi ini kemudian hari dikenal dengan "Fiqh Zakat", walapun disertasi ini sempat tertunda sidangnya, karena sitsuasi politi mesir saat itu"41.

Al-Qardhawi pernah menjadi Imam dan Khatib di masjid-masjid mesir, pernah menjadi pengawas Imam dan Khatib dari kementrian wakaf Mesir, beliau juga pernah menjadi salah satu pengawas lembaga Dakwah dan Irsyad Al-Azhar. Lalu pada tahun 1961M diminta menjadi dekan pada Institut Agama Islam Qatar. Pada tahun 1973M beliau mendirikan Fakultas Tarbiyah Universitas Qatar, lalu kemudian mendirikan program Studi Islam di Universitas Qatar. Dari tahun 1977M beliau diangkat menjadi dekan Fakultas Syari'ah dan Studi Islam sampai tahun 1990M Universitas Qatar. Pada tahun 1991M, beliau memimpin Lembaga Riset As-Sunnah dan Sirah Nabawiyah di Qatar.

Al-Qardhawi menerima pengharagaan Nasional dan Internasional dalam Ilmu pengetahuan dan peradaban Islam. Diantaranya Faishal Awad tahun 1412H dalam Studi ilmu-ilmu Islam. Penghargaan Ilmuan dan Cedikiawan muslim dunia oleh Raja Malaysia tahun 1996M serta penghargaan Kerajaan Brunei Daarussalam Sulthan Hasanul Bolkiah dan Fiqh Islam tahun 1997M².

Al-Qardhawi telah menulis ratusan judul buku Ilmiah dalam berbagai cabang Ilmu Islam dan peradabannya, dalam bidang syari'ah, akidah, akhlak, politik, ekonomi

40 Mahmud Syaltuth, Al-Islam Akidah wa Syari'ah, (Kairo: Daar As-Syuruq, cet. ke-18, 2001), hal 9-10

41 Lihat Isham Talimah, Al-Qardhawi Faqihan, (Kairo: Daar At-Tauzi wa An-Nasyr Al-Islamiy, 2000), hal 11-12

42 Ibid, hal 12-13 
dan sebagainya, beliau juga telah menulis ribuan makalah Ilmiah dan ceramah agama dan keIslaman selama puluhan tahun dibeberapa Negara dunia dengan arah pemikiran Islam moderat.

Pada tahun 2000-an beliau mendirikan Organisasi Persatuan Ulama Dunia atau Al-Ittihad Al-Alamiy Li Ulamail Muslimin (Interntional Union For Muslim Scholars), beranggotakan seluruh ulama besar diberbagai Negara Islam yang professional dalam bidang keIslaman dan peradaban Islam modern. "Beliau merupakan tokoh Islam dunia yang paling berpengaruh dalam dunia Islam dengan konsistensinya pada arah pemikiran moderat dan objektif yang jauh dari ekstremisme dan liberalisme ataupun permisifisme, sebaliknya beliau mampu mensinergikan antara pemikiran salaf dan pembaruan Islam dan antara ajaran yang konstan dan fleksibel yang manfaat pada masa klasik serta maslahat pada zaman modern"43.

\section{Kesaksian para Ulama Dunia tentang Al-Qardhawi:}

Syekh Muhammad Al-Ghazali: "Sungguh Al-Qardhawi adalah salah satu Imam zaman kontemporer, beliau mampu menyatukan antara fiqh teoretik logika dan fiqh atsar riwayat".

Allamah Syekh Musthafa Az-Zarqa: "Al-Qardhawi adalah hujjah zaman kontenporer, dan beliau adalah nikmat Allah terbesar untuk umat Islam.

Syekh Abdul Fattah Abu Ghadah: "Al-Qardhawi adalah faqih abad ini, Mursyid dan Ulama".

Prof. Dr. Thaha Jabir Ulwani: “Al-Qardhawi adalah Fiqh para da'I dan Da'I yang faqih".

Syekh Abdusalam Al-Hirasi: "Al-Qardhawi adalah buah dakwah Imam Hasan AlBanna".

Prof. Dr. Muhammad Imarah: “Al-Qardhawi mampu menyatukan Alimnya para Ahli Muhaddits, Detailnya para Ahli Fiqh dan menyatukan antara hikmahnya syari'at dan kebutuhan zaman".

Syekh Thariq Al-Bisyri: "Kita saat ini berada pada masa Al-Ghazali dan AlQardhawi"44.

Al-Qardhawi adalah ulama kharismatik telah menulis buku-buku yang mengkaji dengan mendalam prinsip pemikiran Islam moderat, sebagaimana pernyataan beliau dalam salah satu Judul tulisannya berkata dalam pengantar bukunya yang berjudul "Fiqh Al-Washathiyah Wa at-tajdid, Ma'lim Wamanaraat". "Hubunganku dengan wasathiyah". "Sungguh Allah telah memuliakanku dengan memperkenalkan arah pemikiran Islam washathiy atau moderasi Islam sejak dahulu. Perjuangan saya itu bukanlah suatu kebetulan, atau menjiplak pendapat seseorang ataupun karena mengikuti hawa napsu. Akan tetapi itu semua itu dikarenakan saya mendapatkan dalildalil yang kuat dan alasan-alasan yang pasti bahwa manhaj washathiyah ini adalah hakikat dan inti ajaran Islam itu sendiri.

${ }^{43}$ Lihat Umar Abdul Karim Sa'dawi, Qadhaya Al-mar'ah fi Fiqh Al-Qardhawi, (Ghiza: Qathrun An-nada, 2006), hal 12-13

44 Ibid, hal 10 
Washathiyah bukanlah pemikiaran Islam yang berorientasi budaya negerinegeri tertentu, sekte-sekte tertentu, mazhab-mazhab tertentu, jama'ah-jamah terntau ataupun karena zaman tententu, namun moderasi Islam adalah hakikat ajaran Islam pertama kali yang diajarkan oleh Nabi Muhammad SAW, sebelum dicemari oleh kotoran pemikiran, dicampuri oleh tambahan-tambahan bid'ah, dipengarhi oleh perbedaan-perbedaan pendapat dalam tubuh umat, diterpa oleh pandangan arah-arah dan sekte-sekte Islam dan diwarnai oleh ideologi-idiologi asing. Aku telah membangun memperkenalkan kembali konsep pemikiran Islam washathiyah atau moderasi Islam ini sejak lebih dari setengah abad yang lalu, dimana saya membahasnya dengan jelas pada bagian pendahuluan buku saya yang berjudul Al-Halal wal Haram fi Al-Islam (Halal dan Haram dalam Islam) yang terbit tahun 1960"45.

Al-Qardhawi dapat dikatakan bahwa beliau adalah bapak moderasi Islam modern. Qardhawilah ulama pertama di zaman modern yang memperkenalkan kembali ajaran moderasi Islam. Al-Qardhawi juga telah menulis konsep arah pemikiran Islam moderat ini dalam buku-bukunya yang lain, diantaranya bukunya yang berjudul "Syari'ah Islamiyah Shalih liltathbiq fi Kullli zamanin Wamakanin, terbit di kairo tahun 1972, Al-Khashais Al-Ammah Lil Islam, terbit di Kairo, tahun 1977, Fi Fiqh Aulawiyat, terbit di Kairo tahun 1994, Tsaqafatuna bainal Infitah wal Inghilaq, terbit di kairo tahun 2000, Khitabuna Al-Islamiy fii Ashril Aulamah, terbit di Kairo tahun 2003, Dirasah fi Fiqh Maqashid As-Syari'ah, terbit di Kairo tahun 2005 dan buku beliau terbaru yang lebih membahas lebih khusus dan detail tentang Washathiyah adalah buku yang bejudul "Figh Al-Washathiyah Wa at-tajdid, Ma'lim Wamanaraat, terbit di Doha tahun 2009 serta buku-bukunya yang lain yang beliau tulis setelah karyakarya tersebut, dimana Al-Qardhawi selalu memberikan warna setiap karyanya dengan manhaj washathiyah ini.

Jadi kalau kita para Ilmuan Islam mau jujur dan objektif, maka mestinya kita mengakui bahwa bapak Manhaj Washathiyah atau moderasi Islam modern, adalah Imam Professor Doktor Yusuf Al-Qardhawi. Semua karya, kajian dan tulisan yang terkait dengan moderasi Islam di dunia Islam adalah kelanjutan dan mengikuti AlQardhawi, bahwa manhaj dan pemikiran Islam tentang washathiyah tidah boleh dibelokkan lagi kepada arah yang lain seperti liberalism dan lainnya, walapun memang telah ada isyarat dan prinsip-prinsip utamanya dalam Al-Qur'an dan As-Sunnah tentang ajaran washathiyah ini. Semoga Allah swt memberikan ganjaran pahala yang terus menerus kepada beliau. Amiin.

\section{Mengapa Al-Qardhawi layak disebut Bapak Moderasi Islam?}

Ada tiga alasan mengapa penulis menilai dan menyimpulkan bahwa Syekh yusuf Al-Qardhawi adalah Ulama kontenporer yang paling layak disebut bapak moderasi Islam era modern, dan layak menjadi rujukan moderasi Islam yang shahih dan tepat. Bukan berarti ulama-ulama lainnya tidak layak menjadi rujukan, namun dalam konteks Ijtihad wasathiyah, karya ilmiah dan konsistensi memperjuangkan arah

${ }^{45}$ Yusuf Al-Qardhawi, Fiqh Al-Wasathiyah Wa at-tajdid, Ma'lim Wamanaraat, (Doha: Markaz Al-Qardhawi Lilwashathiyah Al-Islamiyah wa At-Tajdid, 2009), hal 11-12 
pemikiran Islam moderat di era modern dan era globalisasi, maka Syekh Yususf AlQardhawi adalah tokoh dan ulama yang paling mumpuni dan konsisten terhadap arah pemikiran Islam moderat.

Pertama: Al-Qardhawi adalah ulama abad 21 yang sangat paham terhadap maqashid syari'ah dan thuruq Istinbath Nushus Syar'iyah di era modern. Al-Qardhawi mampu berijtihad menjawab problematika dan isu-isu keIslaman kontnporer dalam bingkai Al-Qur'an dan As-Sunnah, lalu disinergikan dengan kondisi umat Islam modern. Pandangan dan Ijtihad Al-Qardhawi dalam masalah fiqh Syariah, tsaqafah Islamiyah kontenporer dan dalam mensosialisasikan serta mendakwah Islam wasathiyah, sebagai bukti beliau adalah tokoh yang sangat sulit dicari bandingannya dalam dunia Islam. Al-Qardhawi berusaha melakukan modernisasi dan revitalisasi hukum-hukum Islam dan Syariah sesuai dengan budaya dan kondisi manusia modern dalam banyak karya ilmiahnya. Diantaranya adalah karya beliau yang berjudul " $A l$ Halal wal haram fi Al-Islam”, Fiqh Zakat, Fatawa Muashirah, Kaifa nata'amal ma'a Al-Qur'an Al-Adzim, kaifa nata'amal ma'a As-Sunnah An-Nabawaiyah, kaifa nata'amal ma'a At-turats. Dalam buku-buku ini, Al-Qardhawi telah melakukan moderniasi dan revitalisasi Istilah-istilah syari'ah yang masih kuno dalam kita-kitab fiqh klasik menjadi Istilah-istilah yang dapat dicerna dan dipahami oleh umat Islam dalam konteks modern dan budaya global. Realitas ini dapat dibuktikan dengan banyaknya pengehargaan dunia terhadap karya ilmiah dan ijtihad beliau dalam ilmuilmu keIslaman, juga pengakuan para Ulama dunia terhadap kompetensi dan konsistensi beliau terhadap arah pemikiran moderat, sebagaimana telah disebutkan di atas.

Kedua: Al-Qardhawi adalah ulama kontemporer yang pertama kali memperkenalkan kembali manhaj wasathiyah di dunia Islam. Walaupun dasar-dasar arah pemikiran wasathiyah ini telah dipraktekkan oleh Nabi saw, para sahabat, salaf shaleh dan ulama-ulama sebelumnya, namun usaha memperkenalkan kembali dan mengkajinya secara rinci serta mensosialisasikannya di dunia Islam modern dalam kurun waktu lama, maka Yusuf Al-Qardhawi adalah orangnya. Sejak tahun 1959 sampai saat ini tahun 2019, Yususf Al-Qardhawi telah memperkenalkan kembali pemikiran dan manhaj wasathiyah kepada umat Islam lewat tulisan-tulisannya dan karya-kaya ilmiahnya yang diakui oleh Ulama dunia, dimana umat masih terpolarisasi kepada pemikiran yang kaku dan ekstrim pada masalah-masalah syari'at, sehingga umat merasakan beratnya syari' ah dan ajaran Islam.

Ketiga: Al-Qardhawi adalah ulama yang paling konsisten dan cerdas mempertahankan manhaj wasathiyah. Hampor semua karyanya tentang syari'ah, akidah, akhlak, politik Islam, ekonomi Islam, pendidikan Islam, dakwah Islamiyah, pemikiran Islam dan lain sebagainya selalu berwarna arah pemikiran wasathiyah, walapun sikap beliau ini mendapat tantangan dan serangan yang luar biasa dari kelompok Islam terkstual, dzahiriyah dan kaum puritan, juga kelompok liberal dan permisifisme. Al-Qardhawi pernah difatwakan oleh sebagian ulama arah tekstual dan dzahiriyah (arah yang melihat terks dalil) ekstrem sebagai ulam sesat dan ahlul bid'ah. Bahkan dunia barat berniat membunuhnya lewat tangan-tangan peguasa dunia arab, karena khawatir dengan pemikiran moderatnya dapat menjadi besar dan dapat 
menyatukan dunia Islam dalam segala hal. Beberapa penguasa negeri Arab pernah ingin memenjarakannya dan mendesak pemerintah Qatar menyerahkan Al-Qardhawi untuk diadili dan dipenjara karena perjuanganya mendukung arah dan gerakan pemikiran Islam moderat.

Akan tetapi semua tantangan dan ancaman yang ditujukan padanya karena konsistensinya terhadap arah pemikiran wasathiyah ini, tidak membuat Al-Qardhawi mundur dan lemah dalam tulisan dan ceramah-ceramhnya untuk terus menyuarakan ajaran Islam dan moderasinya di dunia, baik lewat tulisan-tulisannya maupun lewat murid-muridnya di seluruh dunia. 


\section{Daftar Pustaka}

Abu Hamid Al-Ghazali, Ihya Ulumiddin, Kairo: Al-Maktabah A-taufiqiyah, 2003

Abu Ishaq As-Syatibi, Al-Muwafaqat fii Ushul As-Syariah, Kairo: al- maktabah at-taufiqiyah, 2003

Ali Muhammad As-Shalabiy, Al-Wasathiyah fil Qur'an Al-Karim, Kairo: Mu'assasah Iqra' Linasyri watauzi wattarjamah, 2007

Hasan Al-Banna', Majmu'ah Ar-Rsail, Kairo: Daar At-tauzi' wa An-Nasyr AlIslamiy, 1992

Ibnu Jarir At-Thabari, Tafsir At-Thabari, Kairo: Maktabah At-Taufiqiyah, 2004 Ibnu Katsir, Tafsir Al-Quran Al-adzim, Beirut: Daar Al-Fikri, 1994)

Ibnu Taimiyah, Majmu'ah Al-Fatawa Li Syaikhil Islam Ahmad bin Taimiyah, Al-Manshurah: Daar Al-Wafa, cet-3, 2005)

Isham Talimah, Al-Qardhawi Faqihan, Kairo: Daar At-Tauzi wa An-Nasyr AlIslamiy, 2000

Mahmud Syaltuth, Al-Islam Akidah wa Syari'ah, Kairo: Daar As-Syuruq, cet. ke-18, 2001

Muhammad Abu Zahrah, Zahrah At-Tafasir, Daar Al-Fikr Al-Arabiy, 2000

Muhammad Al-Khair Abdul Qadir, Ittijahaat Haditsah fi Al-Fikr Al-Almani, Khurtum: Ad-Daar As-Sudaniyah Lil Kutub, 1999

Muhammad bin Ahmad Al-Anshari Al-Quthubi, Al-Jami' Li Ahkam Al-Quran (Tafsir Al-Qurthubi), Kairo: Maktabah Al-Iman, tt

Umar Abdul Karim Sa'dawi, Qadhaya Al-mar'ah fi Figh Al-Qardhawi, Ghiza: Qathrun An-nada, 2006

Yusuf Al-Qardhawi, Fiqh Al-Wasathiyah Wa at-tajdid, Ma'lim Wamanaraat, Doha: Markaz Al-Qardhawi Lilwashathiyah Al-Islamiyah wa At-Tajdid, 2009 